\title{
The Kashmir Dispute since 1947
}

Philip Constable

University of Central Lancashire, UK

\begin{abstract}
:
The Kashmir conflict was a legacy of the partition of India in 1947. Both India and Pakistan claimed sovereignty over Kashmir leading to regional wars in 1947-48, 1965 and 1999, as well as to its relevance in the secession of Bangladesh in 1971. The Kashmir conflict drew international attention during the Cold War as the United States, USSR and China sought to have strategic influence in South Asia, while preferring not to be militarily involved. Within this dispute, Kashmir pursued its own autonomy and independence of regional power interference from the late 1940s. This movement, initially under the National Conference Party led by Sheikh Abdullah, turned to the militant insurgency of the JammuKashmir Liberation Front in the 1980s. Kashmir reflects the difficulties that India and Pakistan have experienced since 1947 in terms of nationalist secession and the increasingly militant measures that nationalist insurgencies have taken for autonomy and independence.
\end{abstract}

Main Text:

The Kashmir dispute has its roots in the British colonial period and partition of BritishIndia between India and Pakistan in 1947. British rule had utilised Hindu-Muslim communal tensions to divide nationalist opposition into a majority Hindu Congress Party and minority Muslim League from the 1920s. These divisions became magnified by wider electorates after 1935 leading to Muslim League concern over the influence of a majority Hindu Congress in an independent India and consequently demands for a Pakistani state. A logic of partition became the strategic consolidation of two sovereign states focused around acceptance or rejection of a two-nation theory which affirmed that Muslims were a separate nationality in South Asia and regions with Muslims in a demographic majority in the northwest and northeast should form a separate nation-state. Kashmir became caught up in this logic of partition.

The princely-state of Jammu-Kashmir under indirect British rule of the Dogra Rajput Maharaja Hari Singh posed a dilemma at partition because the population was four million or 75 percent Muslims and 20 percent Hindus. It was decided that princely states would be 
incorporated into India and Pakistan with respect to their majority populations in association with the accession decisions of their rulers. Hence in demographic terms (as well as communication and river supply) Pakistan claimed Kashmir. Singh however prevaricated in the form of a standstill agreement in the hope of Kashmiri independence, but in the face of Muslim revolt with Pakistani militia support in Poonch province, he signed an instrument of accession to India on 26 October 1947 (Singh, 1947 in Aggarwal and Agrawal, 1995: 37-39). On the basis of Singh's accession, the Indian prime-minister Jawaharlal Nehru (1947-64) dispatched Indian troops to secure Jammu-Kashmir. A UN resolution in 1948 proposed the withdrawal of both Pakistani and Indian forces from Kashmir and confirmed that in a princely state where the ruler's accession appeared to be contrary to the will of the people a plebiscite should be held to determine the future of the state (UN 1948 in Aggarwal and Agrawal 1995: 107-12). Both countries refused to withdraw and the first Indo-Pakistan war from 1947 to 1948 left Kashmir divided between Pakistani Azad (Free) Kashmir and Indian Jammu-Kashmir. From the Indian perspective, Jammu-Kashmir had legally acceded to India, and Pakistani support of insurgency and military invasion were hostile acts towards India. From the Pakistani viewpoint, Singh was prevented from accession to India by his standstill agreement and the Muslim majority of Kashmiri people. The legacy was deadlock over Kashmir.

Subsequently the National Conference Party of Sheikh Abdullah won all the seats in the Jammu-Kashmir Constituent Assembly elections in 1951 (during a boycott by the proPakistan Muslim League), which, in spite of UN objections, was interpreted by India as a plebiscite in its favour. Article 370 of the Indian constitution nonetheless bestowed autonomous status on Jammu-Kashmir within the Indian union. When Sheikh Abdullah began to indicate that Kashmiris wished for more than autonomy, he was jailed in 1953, Singh was deposed in 1953, and Jammu-Kashmir declared an integral part of India in 1956. In this sense, Jammu-Kashmir was included into India and deadlock turned into hostility between Pakistan and India. The conflict wrote large in international terms the HinduMuslim communal paradigm of colonial years, but increasingly became motivated by economic and geostrategic concerns of state consolidation and identity. On the Pakistani side, the conflict built insecurity into the structure of the state as it faced its larger neighbour's control over Jammu-Kashmir and challenge to its claim to be a homeland for all Muslims. On 
the Indian side, while the accession of Muslim-majority Kashmir affirmed Nehru's vision of a secular, federal and pluralist Indian state, it proved a drain on resources and undermined Nehru's anti-imperialist stance in the Non-alignment movement as India itself appeared to be an imperialist power to smaller states like Pakistan.

Pakistan's inability to pressure India into resolving the Kashmiri issue led to its president Ayub Khan (1958-69) seeking international alliance to give Pakistan military and economic resilience against the Indian threat over Kashmir. In 1954 Pakistan first sought support from the United States in the Mutual Defence Assistance Agreement and became a member of SEATO. When Nehru appealed to the United States for military support during the SinoIndian War in 1962, Pakistan hoped that its US ally would pressure India over Kashmir, but the Birch-Grove Statement in 1963 did not make military assistance conditional on resolution of the Kashmir dispute. Feeling betrayed by the United States, Pakistan turned to bolster its security in Kashmir by securing new allies in the People's Republic of China (PRC) and the USSR. In 1964 the PRC supported Pakistan's claim to Kashmir and the USSR withdrew support for India over Kashmir in the UN. Ayub Khan sought to use Soviet concerns over Chinese influence in Asia and US assistance to India in the early 1960s to generate support from both communist countries for Pakistan over Kashmir as a counter-balance to US ambivalence. Hindu-Muslim communal tension which had turned into regional conflict over consolidation of national territory and identity was thereby involved in Cold War rivalries.

By the mid-1960s, on the one hand, India was less stable as a result of the Sino-Indian War in 1962 and Nehru's death in 1964. On the other hand, Pakistan was stable after a referendum on Ayub Khan's presidency in 1965, foreign economic development of Pakistan, and multi-lateral support from the PRC and USSR over Kashmir. In this context, Pakistan's prime minister Zulfikar Ali Bhutto re-invoked the issue of a plebiscite over Kashmir in a climate of communal tension within Kashmir itself. For Bhutto, modernisation of the Indian army with US and Soviet weaponry meant an ever-diminishing opportunity for a Pakistani military operation to secure Kashmir. Nehru continued to refuse a plebiscite until Pakistan withdrew from Azad Kashmir, so on 1 September 1965 the Pakistani army invaded in support of an instigated Kashmiri Muslim insurgency. The Indian army counterattacked across Pakistan's southern border towards Lahore in a twenty-three day war which led to a return to the status quo ante. From the Pakistani side, its allies appeared perfidious in terms 
of the United States, which placed an arms embargo on both countries to limit warfare, or non-committal on the part of the USSR which negotiated an agreement at Tashkent in January 1966 that sought to limit future conflict (Sastri-Khan 1966 in Aggarwal and Agrawal 1995: 443-45). Communal tension turned national war was not indelibly over-written with Cold War policies of containment and both the United States and USSR emphasised a negotiated resolution.

The repercussion of this second Indo-Pakistan war was to accelerate demands for autonomy by the Awami League led by Sheikh Mujibur Rahman in East Pakistan. With East Pakistan separated geographically from West Pakistan by India, the Awami League realised that they had much to lose in economic, political and security terms by involvement in West Pakistan's conflict with India over Kashmir. India's prime minister Indira Gandhi also saw benefit in fostering East Pakistan's secession from West Pakistan because it would reduce the two-sided military threat to India from Pakistan and undermine Pakistan's two-nation theory as a claim on Kashmir. When the Awami League won a majority in East Pakistan in the 1970 elections and Pakistan's president General Yahya Khan annulled the elections through martial law, India supported the Awami League's guerrilla war against the West Pakistan army leading to a third regional war on 3 December 1971. As in the 1965 war, the United States and PRC did not become directly involved. However as a consequence of its new Indo-Soviet Friendship Treaty of 1971, the USSR vetoed a UN ceasefire resolution, which contributed to Indian success and Bangladeshi secession from Pakistan. In terms of Kashmir, the postwar Simla Agreement in July 1972 recognised the partition of Kashmir along the ceasefire line of control, which gave India geo-strategic advantage and obliged Bhutto to accept Azad Kashmir as part of Pakistan (Gandhi-Bhutto 1972 in Aggarwal and Agrawal 1995: 460-62). The applicability of Pakistan's two-nation theory as justification for its right to Jammu-Kashmir was undermined, while Bangladesh's secession contributed to continuing Kashmiri hopes of independence from both India and Pakistan.

India found Jammu-Kashmir's domestic politics increasingly unmanageable. The imprisonment of Sheikh Abdullah during the Nehru and Gandhi eras saw a gradual accommodation of the National Conference Party with the Indian Congress Party. Sheikh Abdullah's Plebiscite Front continued to demand a plebiscite to determine the future of Kashmir, but his 1975 Accord with Gandhi recognised Kashmir's accession to India under 
the proviso of its autonomy in Article 370 and he became chief minister from 1975 to 1982 (Gandhi-Abdullah 1975 in Aggarwal and Agrawal, 1995: 470-71). By the mid 1980s, younger Kashmiri had however come to believe that both the National Conference Party led by his son Farooq Abdullah and the Congress Party had achieved limited improvement for Jammu-Kashmir. In consequence pro-Pakistani groups, and Kashmiri separatists like the Jammu-Kashmir Liberation Front founded by Maqbool Bhat and Amanullah Khan turned to militant insurgency against India after the disputed 1987 elections and the Gawakadal Bridge killings by Indian security forces in 1990. This insurgency was also sustained by combatants returning from the Afghan-Soviet war (1979-89) with Pakistani military support. India was faced with the dilemma of either military containment of militant Kashmiri separatists with concomitant criticism of Indian human rights abuses or further devolution of power to moderate Kashmiri politicians which meant acceptance of moderate and militant demands for a plebiscite on Kashmiri self-determination in accordance with the U.N. resolution in 1948. The latter was a step that India had been reluctant to take since 1948 and insurgency consolidated a Kashmiri independence movement with Pakistani support.

Following the Simla Agreement in 1972, large-scale Indo-Pakistani military engagement in Kashmir reduced, except for attempts to secure the line of control across the Siachen Glacier after 1984. Within the context of ongoing Kashmiri insurgency from 1987 and testing of nuclear arsenals (India from 1974 and Pakistan in 1998), the Indian prime minister A. B. Vajpayee visited Pakistan's prime minister Nawaz Sharif in February 1999 to discuss the Kashmir issue. The resultant Lahore Declaration promised bilateral cooperation to resolve border disputes, but a few months later the Pakistani army occupied Indian positions across the line of control in the Kargil mountains, which Indian troops vacated during winter months. Pakistani occupation of the Kargil range allowed them to block the strategic road between the Kashmir Valley and Ladakh as a bargaining position for Indian withdrawal from the Siachen Glacier and international discussion of the Kashmir issue. Pakistani occupation resulted in sustained Indian military action to eject Pakistani forces. As in the 1965 and 1971 conflicts, the PRC proved unresponsive to Pakistan's appeal for support, the United States pressured Pakistan to withdraw, and the UN refused to reopen debate on a plebiscite. The Kargil war from May to July 1999 therefore failed as did the 1965 war to internationalise Pakistani claims or debate within Kashmir on its right to self-determination. 
In sum, Hindu-Muslim communal tensions from the British colonial period became internationalised as a national dispute over Kashmiri territory between India and Pakistan after 1947 on the basis of each state's strategic consolidation and projected primary identity, namely a Muslim nation-state in Pakistan and a secular, pluralist but Hindu majority state in India. This nationalist dispute over Kashmir was imbricated in super-power politics during the Cold War, although the United States, USSR and PRC stayed detached from direct involvement. Kashmiri voices for independence from regional and international interference were always present from the time of Sheikh Abdullah in the 1940s and 1950s, but it became a militant nationalist insurgency in the late 1980s led principally by the Jammu-Kashmir Liberation Front driven by limitation of Kashmiri political autonomy. Kashmir remains an example of the crisis of unity that both India and Pakistan have experienced since 1947 in terms of a national separatist movement that has been aggravated by the failures of federal governance in addressing Kashmiri aspirations.

\section{Reference:}

Aggarwal, J. C. and Agrawal, S. P. (1995) Modern History of Jammu and Kashmir. New Delhi: Concept Publishing Company.

\section{Suggested Readings:}

Behera, N. C. (2006) Demystifying Kashmir. Washington D.C: Brookings Institute.

Bose, S (2003) Kashmir: Roots of Conflict, Paths to Peace. Cambridge Massachusetts: Harvard University Press

McGarr, P. M. (2013) Cold War in South Asia. West Nyack NY: Cambridge University Press.

McMahon, R. J. (1994) Cold War on the Periphery: The United States, India and Pakistan. New York: Colombia University Press.

Noorani, A. G. (2014) The Kashmir Dispute 1947-2012. New Delhi: Oxford University Press.

Panigrahi, D. N. (2009) Jammu and Kashmir, the Cold War and the West. London: Routledge.

Puri, B. (1995) Kashmir: Towards Insurgency. London: Sangam Books.

Schaffer, H. B. (2009) The Limits of Influence: America's Role in Kashmir. Washington D.C: Brookings Institute.

Scofield, V. (2010) Kashmir in Conflict: India, Pakistan and the Unending War. London: I. B. Taurus.

Snedden, C. (2013) Kashmir: The Unwritten History. New Delhi: Harpers Collins, India. 